\title{
EFFECT OF SOCIAL COMPETENCE AND SCHOOL STRESS ON BULLYING BEHAVIOR IN ADOLESCENT
}

\author{
Indri Eldiorita \\ indrieldiorita@gmail.com
}

Faculty of Psychology Syarif Hidayatullah

State Islamic University Jakarta

\author{
Layyinah \\ ylayyinah@yahoo.com \\ Faculty of Psychology Syarif Hidayatullah \\ State Islamic University Jakarta
}

\begin{abstract}
This research aim to know the cause of bullying increasing, Based on research data that was collected from one of high schools in Jakarta which was found that many student who want to do bullying their friends and there were also many student become a victim of bullying by their own friends. This situation occur to show their exsistance in the school. Based on the previous study, there are many factors that influence bullying behavior, such social competence and school stress. Social competence is regarded as one of the most important protective factors in the prevention of behavioural problems, such bullying behavior (Gundersen, 2010). Besides that, high school stress have positively influence concerning to bullying (Karatzias, Power, Flemming, Lennan \& Swanson, 2010).

Samples amount in this research is students from first, second, and third degree of senior high schools ini Jakarta, academic year 2016/2017. Sampling technique in this study was nonprobability sampling with 205 respondents. This study used quantitative approach with linear regression as analysis method.

Finding : from this study explains that social competence, such cooperative, emphaty and self control and school stress, such teacher interaction influence significantly on bullying behavior on adolescence. It is accordance with the finding of previous studies conducted by Bauman dan Del Rio (dalam Swearer dan Hymel, 2015) dan Irshar dan Atta (2013) that social competence and school stress influence on bullying behavior.
\end{abstract}

Keywords: Bullying Behavior, Social Competence, School Stress

\section{Abstrak}

Penelitian ini dilakukan bertujuan untuk mengetahui penyebab meningkatnya perilaku bullying, SMA di Jakarta. Berdasarkan penelitian sebelumnya, banyak faktor yang mempengaruhi terjadi perilaku bullying, seperti kompetensi sosial dan stres sekolah. Kompetensi Sosial dianggap sebagai slaah satu faktor penting dalam mencegah terjadinya perilaku bermasalah seperti perilaku bullying. Selain itu, stres sekolah yang tinggi juga mempengaruhi terjadinya perilaku bullying.

Sampel dalam penelitian ini adalah siswa kelas satu, dua, dan tiga SMA N Jakarta tahun akademik 2016/2017. Teknik sampling yang digunakan adalah nonprobability sampling dengan 205 responden. Penelitian ini menggunakan pendekatan kuantitatif dengan metode analisa data regresi linier.

Hasil peneltian menjelaskan bahwa kompetensi sosial seperti cooperative, emphaty, dan self control dan stres sekolah seperti teacher interaction mempengaruhi secara signifikan perilaku bullying pada remaja. Hasil penelitian ini sesuai dengan penelitian sebelumnya Bauman dan Del Rio (dalam Swearer dan Hymel, 2015) dan Irshar dan Atta (2013) bahwa kompetensi sosial dan stress sekolah secara signifikan mempengaruhi perilaku bullying.

Kata Kunci: perilaku bullying, kompetensi sosial dan stres sekolah. 


\section{PENDAHULUAN}

Kekerasan di sekolah, khususnya bullying masih menjadi masalah yang serius di banyak sekolah. Menurut Olweus (dalam Benitez \& Justicia, 2006) perilaku bullying adalah perilaku secara fisik dan verbal yang dilakukan oleh seseorang atau sekumpulan orang terhadap orang lain, dilakukan secara berulang-ulang, berkelanjutan dan menyalahgunakan kekuasaan atau kekuatan dengan maksud untuk merugikan korban. Masih banyaknya perilaku bullying di sekolah terbukti dengan kejadian perilaku bullying yang terjadi di SMA 3 Jakarta pada Mei 2016. Pelaku bullying melibatkan enam orang siswa kelas tiga. Mereka memberi hukuman kepada adik kelas yang menyuguhkan penampilan DJ. Salah satu bentuk tindakan bullying yang dilakukan adalah menjadikan kepala adik kelas tersebut sebagai asbak rokok (Rudi, 2016).

Perilaku bullying juga kembali terjadi di SMA 6 Jakarta pada Juli 2016. Padahal, ancaman keras dikeluarkan dari sekolah bagi siswa yang terlibat bullying sudah sering disampaikan. Aksi kekerasan atau bullying terjadi di luar lingkungan sekolah (Rina, 2016). Selain itu, Komisi Perlindungan Anak Indonesia (KPAI) yang mencatat bahwa jumlah anak sebagai pelaku bullying mengalami kenaikan. Berdasarkan data KPAI pada tahun 2014 terdapat 67 kasus dan mengalamipeningkatan menjadi 79 kasus di tahun 2015 kasus anak sebagai pelaku bullying (Himawan \& Saleh, 2015).

Terdapat beberapa kasus bullying lainnya yang terjadi di beberapa sekolah. Pertama, di SMAN 70 Jakarta. Pada Juli 2014, 13 orang siswa di SMAN 70 dikeluarkan akibat melakukan pelanggararan yakni perbuatan bullying pada juniornya. Para senior telah mem-bully 15 siswa yang masih duduk di kelas satu. Kedua, siswa SMPN 4 Binjai, Sumatera Utara. Beredar video yang dilakukan oleh siswa sekolah tersebut dan dalam video itu pelaku tidak hanya memaki, tetapi juga menampar hingga menendang korbannya. Ketiga, siswa baru yang di bully oleh 18 orang senior di SMA Seruni Don Bosco Pondok Indah. Pada tubuh korban didapati beberapa luka memar akibat ulah senior di sekolah tersebut (Susanti, 2015).

Berdasarkan hasil wawancara dengan guru BK di salah satu SMA di daerah Kebayoran Baru, peneliti memperoleh informasi bahwa kasus bullying sering terjadi di sekolah tersebut. Perilaku bullying tersebut terjadi secara verbal dan fisik. Informasi yang mengejutkan adalah junior merasa senang dan ingin di bully oleh seniornya sebagai bukti eksistensi dan pengakuan dari senior di sekolah tersebut. Selain itu, perkelahian antar siswa dan antar sekolah juga sering terjadi.

Dengan adanya Peraturan Gubernur Nomor 16 tahun 2015 tentang pencegahan dan penanganan bullying serta kekerasan di lngkungan sekolah, angka perilaku bullying semakin menurun karena berdasarkan peraturan tersebut siswa yang terlibat dalam perilaku bullying atau tawuran akan langsung dikeluarkan dari sekolah. Meskipun demikian, perilaku bullying tetap saja terjadi, hal ini disebabkan oleh para alumni dan siswa drop out yang mengadu domba antara senior dengan junior. Untuk angka perilaku bullying yang terjadi, peneliti tidak mendapatkan angka pastinya. Hal ini disebabkan oleh sistem administrasi di sekolah tersebut yang sudah tidak mencatat setiap perilaku bullying yang terjadi.

Untuk kegiatan belajar di SMA 6 Jakarta termasuk padat yaitu dari jam 06.30 WIB sampai 15.15 WIB dan kegiatan ekstrakurikuler yang dilakukan setiap hari Jumat. Kurikulum yang dipakai di sekolah ini adalah Kurikulum 2013. Menurut keterangan 
guru BK banyak siswa yang mengeluh dengan padatnya kegiatan sekolah dan tuntutan tugas di sekolah.

Terdapat banyak faktor yang mempengaruhi terjadinya perilaku bullying, salah satunya adalah kompetensi sosial. Menurut Gresham dan Elliot (dalam Smart \& Sanson, 2003) kompetensi sosial dapat diartikan sebagai kemampuan untuk berperilaku yang dapat diterima secara sosial, cara berperilaku yang dipelajari yang memungkinkan seseorang berinteraksi secara efektif dengan orang lain, dan mengarah pada perilaku dan respon-respon sosial yang dimiliki oleh individu.

Sebuah penelitian yang dilakukan oleh Gundersen (2010) menunjukkan adanya hubungan yang kuat antara behavioural problems dan kompetensi sosial.Anak dan remaja dengan kompetensi sosial yang tinggi akan lebih jarang untuk terlibat dalam perilaku bermasalah dan perilaku bullying merupakan salah satu perilaku bermasalah pada remaja. Menurut Roland, Idsoe, dan Vaillancourt (dalam Pepler, Craig, Jiang, \& Connolly, 2008) beberapa anak yang melakukan perilaku bullying memiliki fondasi kompetensi sosial yang buruk untuk interaksi sosial yang positif. Anak yang memiliki kompetensi sosial yang buruk akan lebih tinggi untuk terlibat dalam perilaku bullying.

Sebaliknya menurut Vaillancourt et al (dalam Pepler, Craig, Jiang, \& Connolly, 2008) muncul poin bukti bahwa anak-anak yang melakukan perilaku bullying menunjukkan kemampuan sosial yang tinggi dan dominan dalam grup sebaya. Diperkuat oleh Arsenio Lemerise dan Sutton (dalam Pepler, Craig, Jiang, \& Connolly, 2008) anak-anak dengan kompetensi sosial yang tinggi mampu memanipulasi orang lain, memiliki kepedulian yang rendah untuk bahaya yang mungkin dapat dialami korban, dan berharap bahwa intimidasi merupakan cara yang efektif untuk menegaskan kekuasaan.

Selain kompetensi sosial, stress sekolah merupakan faktor lain yang mempengaruhi terjadinya perilaku bullying. Menurut Helms (dalam Nijbour, 2007) stres di sekolah dapat berhubungan dengan prestasi atau penguasaan materi pelajaran akademik dan evaluasi kinerja; sosial atau berhubungan dengan teman sebaya, interaksi dengan guru, dan partisipasi kegiatan kelas.

Menurut Taki (2001) stres merupakan salah satu faktor penting dalam perilaku bullying dan terdapat beberapa faktor yang dapat menjelaskan penyebab terjadinya bullying diantaranya: konflik dengan teman sebaya dan guru, frustasi dengan kehidupan keluarga dan sekolah.Sebuah penelitian yang dilakukan oleh Tamtomo (2014) yang menguji bagaimana pengaruh stres sekolah terhadap bullying. Hasil penelitian ini menunjukkan bahwa stres sekolah berkorelasi positif secara signifikan dengan perilaku bullying. Jadi dapat diprediksi bahwa semakin tinggi stres sekolah maka semakin tinggi perilaku bullying.

Penulis ingin mengetahui pengaruh kompetensi sosial dan stress sekolah terhadap perilaku bullying pada remaja usia (14-17). Hasil penelitian ini diharapkan dapat melengkapi penelitian sebelumnya terkait dengan pengaruh fungsi psikologis remaja dengan perilaku bullying serta memberikan masukan bagi penelitian terkait dengan perilaku bullying di Indonesia. 


\section{METODE PENELITIAN}

\section{Populasi, sampel, dan teknik pengambilan sampel}

Populasi penelitian yaitu seluruh siswa di SMA N 6 Jakarta tahun ajaran 2016/2017 berjumlah 956 orang. Jumlah sampel yaitu 205 responden terdiri dari siswa kelas satu, dua, dan tiga.

Teknik pengambilan sampel yaitu accidental sampling salah satu teknik non probability sampling. Sampel diperoleh dari setia siswa yang kebetulan bertemu dan bersedia menjadi sampel penelitian. Hal ini sesuai kesepakatan dengan pihak SMA 6 Jakarta bahwa kueisoner diberikan kepada siswa yang sedang tidak dalam kegiatan belajar, sehingga proses pengambilan data tidak menggangu proses belajar siswa di sekolah.

\section{Instrumen penelitian}

Terdapat tiga alat ukur yang digunakan peneliti dalam penelitian ini, yaitu Skala Bullying, skala SSRS (Social Skills Rating System), dan school situation survey(SSS).

1. Skala Bullying. Perilaku bullying diukur menggunakan skala baku yang telah diadopsi dan dimodifikasi oleh peneliti. Skala tersebut adalah Illionis Bullying Scale yang dikembangkan oleh Espelage berdasarkan teori Olweus. Alat ukur ini terdiri dari tiga subskala, yaitu : bullying, victimization, dan fihgting. Namun dalam penelitian ini, peneliti fokus pada pelaku bullying. Alat ukur terdiri dari 9 item.

2. Skala kompetensi sosial. Kompetensi sosial diukur menggunakan alat ukur baku SSRS (Social Skills Rating System) berdasarkan teori Gresham \& Elliot. Peneliti menggunakan kuisioner SSRS versi siswa. SSRS untuk area social skills versi siswa memiliki konsistensi internal .67-.83. Alat ukur ini dimodifikasi dan diadaptasi oleh peneliti yang terdiri dari lima dimensi, yaitu cooperation, assertion, emphaty, responsibility, dan self control dan menggunakan skala model likert dengan pilihan empat jawaban.

3. Skala Stres sekolah. Dalam penelitian ini, peneliti menggunakan alat ukur school situation survey (SSS) berdasarkan teori Helms (dalam Helms 1990) yang dipergunakan oleh siswa kelas satu sampai kelas tiga. Peneliti fokus pada sumber stres sekolah yang terdiri dari 22 item dan menggunakan skala model likert dengan pilihan empat jawaban. 


\section{HASI PENELITIAN}

\section{Analisa deskriptif}

Total sampel pada penelitian ini berjumlah 205 siswa di SMA N 6 Jakarta yang terletak di Kebayoran Baru. Selanjutnya akan dijelaskan gambaran subjek lebih rinci pada tabel 4.1 berikut :

Tabel 4.1

Subjek Penelitian

\begin{tabular}{ccc}
\hline Jenis Kelamin & Jumlah Responden & Presentase \\
\hline Laki-laki & 74 & $36 \%$ \\
Perempuan & 131 & $64 \%$ \\
Total responden & 205 & $100 \%$ \\
\hline
\end{tabular}

\section{Hasil uji hipotesis}

1. Analisa Regresi

Tabel 4.2

Hasil Analisis Regresi

\section{Model Summary}

\begin{tabular}{ccccc} 
Model & $\mathrm{R}$ & R Square & Adjusted R Square & Std. Error of the Estimate \\
\hline 1 & $.520^{\mathrm{a}}$ & .270 & .237 & 8.06983 \\
\hline
\end{tabular}

a. Predictors: (Constant), Cooperative, Assertive, Responsibility, Emphaty,

Selfcontrol, Teacher_Interaction, Peer_Interaction, Academic_Stress,

Academic_Selfconcept

Dari tabel 4.2. dapat diketahui informasi bahwa perolehan nilai $R$-square sebesar 0.270 atau sebesar 27\%. Artinya proporsi dari perilaku bullying yang dijelaskan oleh cooperative, assertive, responsibility, emphaty, self control, teacher interaction, peer interaction, academic stress, dan academic self concept dalam penelitian ini adalah sebesar $27 \%$ sedangkan 73\% lainnya dipengaruhi oleh variabel lain di luar penelitian ini.

\section{Anova keseluruhan IV terhadap DV}

\section{Tabel 4.3}

\section{Hasil Analisis Anova}

\begin{tabular}{|c|c|c|c|c|c|c|}
\hline \multicolumn{7}{|c|}{ ANOVA $^{\mathrm{b}}$} \\
\hline & del & Sum of Squares & Df & Mean Square & $\mathrm{F}$ & Sig. \\
\hline \multirow[t]{3}{*}{1} & Regression & 4707.121 & 9 & 523.013 & 8.031 & $.000^{\mathrm{a}}$ \\
\hline & Residual & 12698.828 & 195 & 65.122 & & \\
\hline & Total & 17405.949 & 204 & & & \\
\hline
\end{tabular}

4.3, dapat diketahui bahwa nilai Sig sebesar 0.000 dengan demikian diketahui bahwa nilai Sig $<0.05$, maka hipotesis nol yang menyatakan tidak ada pengaruh yang signifikan dari dimensi kompetensi sosial (cooperative, assertive, responsibility, emphaty, dan 
self control) dan stres sekolah (teacher interaction, peer interaction, academic stress, dan academic self concept) terhadap perilaku bullying ditolak.

\section{Koefisien regresi variabel perilaku bullying}

\section{Tabel 4.4}

\section{Koefisien Regresi Variabel Perilaku Bullying}

\begin{tabular}{|c|c|c|c|c|c|c|}
\hline \multicolumn{7}{|c|}{ Coefficients $^{\mathrm{a}}$} \\
\hline & & Unstand & d Coefficients & $\begin{array}{l}\text { Standardizea } \\
\text { Coefficients }\end{array}$ & & \\
\hline \multicolumn{2}{|c|}{ Model } & B & Std. Error & Beta & $\mathrm{t}$ & Sig \\
\hline \multirow[t]{10}{*}{1} & (Constant) & 65.701 & 13.626 & & 4.822 & .000 \\
\hline & Cooperative & -.276 & .082 & -.269 & -3.352 & .001 \\
\hline & Assertive & .114 & .089 & .111 & 1.280 & .202 \\
\hline & Responsibility & .126 & .090 & .120 & 1.390 & .166 \\
\hline & Emphaty & -.200 & .083 & -.185 & -2.414 & .017 \\
\hline & Selfcontrol & -.207 & .082 & -.189 & -2.529 & .012 \\
\hline & Teacher_interaction & .255 & .076 & .249 & 3.361 & .001 \\
\hline & Peer_interaction & -.128 & .091 & -.123 & -1.404 & .162 \\
\hline & Academic_stress & -.012 & .075 & -.011 & -.164 & .870 \\
\hline & Academic_selfconcept & .015 & .098 & .012 & .153 & .879 \\
\hline & ependent Variable: $B U L$ & & & & & \\
\hline
\end{tabular}

Berdasarkan tabel 4.4 di atas, dapat diketahui bahwa terdapat empat variabel yang signifikan mempengaruhi perilaku bullying, yaitu cooperative dengan signifikansi 0.001 , emphaty dengan signifikansi 0.017 , self control dengan signifikansi 0.012 dan teacher interaction dengan signifikansi 0.001 .

\section{Proporsi varians}

Untuk proporsi varians dari masing-masing Independent variable terhadap perilaku bullying terdapat empat variabel yang secara signifikan memberikan sumbangan terhadap varians perilaku bullying, yaitu:

1. Variabel cooperative menyumbang sebesar $12 \%$ terhadap varians perilaku bullying yang nilainya signifikan dengan Sig. F-Change $=0.000$ (Sig. F Change $<0.05$ ), dengan nilai $F$ Change $=27.573$, df1 $=1$ dan $\mathrm{df} 2=203$.

2. Variabel emphaty memberikan sumbangan sebesar $2.9 \%$ terhadap varians perilaku bullying. Sumbangan tersebut signifikan dengan Sig.F Change $=0.009$ (Sig. F Change $<0.05)$, dengan nilai $\mathrm{F}$ Change $=6.995$, df1 $=1$ dan $\mathrm{df} 2=200$.

3. Variabel self control memberikan sumbangan sebesar $6.2 \%$ terhadap varians perilaku bullying. Sumbangan tersebut signifikan dengan Sig.F Change $=0.000$ (Sig. $\mathrm{F}$ Change $<0.05)$, dengan nilai $F$ Change $=15.855$, df1 $=1$ dan df2 $=199$. 
4. Variabel teacher interaction memberikan sumbangan sebesar $4.2 \%$ terhadap varians perilaku bullying. Sumbangan tersebut signifikan dengan Sig.F Change $=0.001$ (Sig. F Change $<0.05$ ), dengan nilai $\mathrm{F}$ Change $=11.408$, df $1=1$ dan $\mathrm{df} 2=198$.

\section{SIMPULAN}

Berdasarkan hasil analisis data dapat disimpulkan bahwa ada pengaruh yang signifikan dari kompetensi sosial (cooperative, assertive, responsibility, emphaty, dan self control) dan stres sekolah (teacher interaction, peer interaction, academic stress, dan academic self concept) terhadap perilaku bullying pada remaja. Jika dilihat dari nilai koefisien regresi, peneliti mendapatkan empat variabel yang signifikan mempengaruhi perilaku bullying pada remaja, yaitu cooperative, emphaty, self control dan teacher interaction. Dengan demikian, lima variabel lainnya tidak mempengaruhi perilaku bullying secara signifikan, lima variabel tersebut adalah assertive, responsibility, peer interaction, academic stress, dan academic self concept.

Jika dilihat dari nilai proporsi varians, sumbangan independent variable yang signifikan mempengaruhi perilaku bullying terdapat empat variabel yaitu, cooperative, emphaty, self control, dan teacher interaction. Untuk kelima variabel lainnya dalam penelitian ini tidak signifikan mempengaruhi perilaku bullying.

\section{DISKUSI}

Hasil pengujian hipotesis pengaruh kompetensi sosial dan stres sekolah terhadap perilaku bullying yang dilakukan peneliti menunjukkan bahwa ada pengaruh yang signifikan dari variabel kompetensi sosial yang terbagi menjadi lima dimensi yaitu cooperative, assertive, responsibility, emphaty, self control dan stres sekolah yang terbagi menjadi empat dimensi yaitu teacher interaction, peer interaction, academic stress, academic self concept. Dari hasil analisis regresi, peneliti mendapatkan bukti bahwa terdapat pengaruh dari kompetensi sosial dan stres sekolah terhadap perilaku bullying.

Berdasarkan hasil nilai koefisien regresi penelitian ini, terdapat empat variabel yang mempengaruhi secara signifikan terhadap perilaku bullying, keempat variabel tersebut adalah cooperative, emphaty, self control dan teacher interaction. Selanjutnya lima variabel lainnya seperti assertive, responsibility, peer interaction, academic stress, dan academic self concept tidak memiliki pengaruh yang signifikan terhadap perilaku bullying.

Cooperative dalam penelitian ini merupakan cara bertindak yang sesuai dengan peraturan yang ada, mampu bekerja sama dengan orang lain atau bekerja dalam tim dan dapat menolong orang lain. Dalam penelitian ini cooperative ditemukan sebagai variabel yang berpengaruh secara negatif terhadap perilaku bullying, artinya semakin tinggi cooperative seseorang, maka akan semakin rendah perilaku bullying, Hal ini sesuai dengan penelitian yang dilakukan oleh Pereen \& Alsaker (2006) yang menyatakan bahwa orang yang melakukan perilaku bullying memiliki cooperative lebih rendah dibandingkan dengan yang tidak melakukan perilaku bullying. Diperkuat lagi oleh Ttofi \& Farrington (2011) yang menyatakan bahwa terdapat beberapa cara untuk mengurangi perilaku bullying salah satunya yaitu dengan meningkatkan perilaku cooperative dalam kelompok. 
Emphaty dalam penelitian ini berpengaruh secara signifikan terhadap perilaku bullying. emphaty dan perilaku bullying berkorelasi negatif, artinya semakin tinggi emphaty maka akan semakin rendah perilaku bullying seseorang atau sebaliknya. Hal ini sesuai dengan pendapat Ozkan \& Cifci yang menyatakan bahwa emphaty memberikan kontribusi untuk mengurangi perilaku bullying antar teman sebaya. Hasil ini juga didukung oleh banyak penelitian, seperti hasil penelitian Olweus (Jolliffe \& Farrington, 2006) yang menyatakan bahwa pelaku bullying kurang emphaty terhadap korban. Selain itu menurut Smith \& Thompson (Jolliffe \& Farrington, 2006) anak yang melakukan perilaku bullying menunjukkan perasaan emphaty yang kurang terhadap korban.

Self control juga termasuk variabel yang signifikan mempengaruhi perilaku bullying dengan korelasi negatif. Artinya semakin tinggi self control maka akan semakin rendah perilaku bullying seseorang. Hal ini sesuai dengan pendapat Macklem, Rigby, Sullivan (dalam Milson \& Gallo, 2006) bahwa dengan self control seseorang dapat mengendalikan diri dan berfikir terlebih dahulu sebelum bertindak. Dari pendapat ini bisa kita ambil kesimpulan bahwa orang yang melakukan bullying memiliki self control yang rendah. Diperkuat oleh hasil penelitian Moon \& alarid (2014) bahwa remaja dengan self control yang rendah kemungkinan besar melakukan perilaku bullying fisik dan psikologis.

Variabel berikutnya yang berpengaruh secara signifikan dalam perilaku bullying adalah teacher interaction, dimana teacher interaction berkaitan dengan bagaimana proses interaksi antara siswa dengan guru dan bagaimana persepsi siswa terhadap sikap guru tersebut. Hal ini sejalan dengan penelitian Bauman \& Del Rio (dalam Swearer dan Hymel, 2015) yang mana hasil penelitiannya menyatakan bahwa tingginya perilaku bullying memiliki hubungan erat dengan respon guru, hubungan yang tidak dekat antara siswa dan guru dan rendahnya dukungan dari guru. Diperkuat juga oleh yang menyatakan bahwa hubungan antara siswa dengan guru menjadi prediktor terjadinya perilaku bullying. Menurut Morrison (dalam Petrie, 2014) ketika seseorang memiliki hubungan yang kurang dekat dengan orang lain dapat meningkatkan resiko perilaku agresi kepada orang lain. Terutama guru dianggap sebagai orang tua kedua bagi siswa. Jadi sangat penting bagi siswa untuk memiliki hubungan yang positif dengan guru dan memiliki persesi yang baik kepada guru.

Adapun aspek kompetensi sosial yang tidak berpengaruh dalam penelitian ini adalah assertive dan responsibility. Assertive yang berkaitan dengan kemampuan memperkenalkan diri, mengajak orang lain, menanyakan informasi kepada orang lain. Siswa SMA N 6 yang menjadi responden dalam penelitian ini memiliki kemampuan assertive yang cukup tinggi. Hal ini sejalan dengan pendapat Keliat, Tololiu, Daulima, dan Erawati (2015) yang menyatakan bahwa remaja yang tidak mampu mengembangkan perilaku assertive, akan lebih mudah untuk terlibat perilaku agresif salah satu contohnya yaitu perilaku bullying.

Secara keseluruhan, beberapa variabel kompetensi sosial yang tidak signifikan diasumsikan karena kompetensi sosial merupakan variabel yang sangat luas dan terdapat teori yang lebih kecil yang berkaitan dengan masing-masing dimensi kompetensi sosial. Oleh karena itu, item masing-masing variabel belum dapat sepenuhnya menggali informasi dari setiap dimensi. 
Dalam penelitian ini ditemukan juga bahwa aspek-aspek stres sekolah lainnya seperti peer interaction, academic stress, dan academic self concept tidak memiliki pengaruh yang signifikan terhadap perilaku bullying. Pada variabel academic stress dan academic self concept, hasil penelitian ini bertentangan dengan penelitian yang dilakukan oleh Milson \& Gallo (2006) yang menyatakan bahwa terdapat prestasi akademik yang rendah berpengaruh terhadap terjadinya perilaku bullying. Hal ini juga bertentangan dengan penelitian oleh Inamura, Takano, Nihon Bengoshi Renmei, Inoue, Kobayashi (dalam Yoneyama \& Naito, 2010) tekanan prestasi akademik merupakan salah satu faktor yang erat hubungannya dengan perilaku bullying pada siswa. Hasil penelitian yang tidak signifikan didukung oleh Swearer \& Hymel (2015) yang menyatakan bahwa bullying disekolah lebih disebabkan oleh hubungan antara siswa dengan guru.

Terakhir variabel peer interaction dalam penelitian ini tidak berpengaruh secara signifikan terhadap perilaku bullying. Hal ini sejalan dengan penelitian Petrie (2014) yang menyatakan bahwa tidak terdapat pengaruh yang signifikan antara perilaku bullying dengan peer relation dan belonging.

Penulis menyadari terdapat beberapa kekurangan dalam penelitian ini, salah satunya adalah jumlah sampel yang hanya berjumlah 205 orang, hal ini dikarenakan responden dalam penelitian ini hanya siswa yang sedang tidak dalam proses PBM (Proses Belajar Mengajar). Keterbatasan lainnya adalah masih banyak responden yang tidak jujur dalam mengisi kuesioner. Hal ini dikarenakan karena kuesioner yang mereka isi berkaitan dengan perilaku bullying yang merupakan salah satu perilaku yang sensitif. Selain itu, masih banyak variabel yang belum disertakan sepeti kepribadian yang seharusnya menjadi faktor penting untuk membedakan satu orang dengan yang lainnya. 


\section{DAFTAR PUSTAKA}

Benitez, J. L., \& Justicia, F. (2006). Bullying: description and analysis of the phenomenon. Electronic Journal of Research in Educational Psychology, 151170.

Dautenhahn, K., \& Woods, S. (2003). Possible Connections between Bullying Behaviour, Empathy and Imitation. UK : Faculty of Engineering and Information Sciences University of Hertfordshire.

Gundersen, K. K. (2010). Reducing behaviour problems in young people through social competence programmes. The International of Emotional Education , 48-62.

Irshad, E., \& Atta, M. (2013). Social Competence as Predictor of Bullying among Children and Adolescents. Journal of the Indian Academy of Applied Psychology , 35-42.

Karatzias, A., Power, K. G., Flemming, J., Lennan, \& Swanson, V. (2002). The Role of Demographics, Personality Variables and School Stress on Predicting School Satisfaction/ Dissatisfaction: Review of the literature and research findings. Educational Psychology: An International Journal of Experimental Educational Psychology , 33-50.

Keliat, B.A., Tololiu, T. A., Daulima, N.H.C., \& Erawati, E. (2015). Effectiveness Assertive Training of Bullying Prevention Among Adolescents in West Java Indonesia. International Journal of Nursing, 2 (1), 128-134.

Milson, A., \& Gallo, L. L. (2006). Bullying in Middle Schools: Prevention and Intervention. Middle School Journal, 12- 19.

Nijboer, M. (2007). Childhood Stress : Stressor, Coping, and Factors. Literature Study. Belanda : University of Groningen.

Pepler, D., Craig, W., Jiang, D., \& Connolly, J. (2008). Developmental Trajectories of Bullying and Associated Factors. Child Development, 325-338.

Perren, S., \& Alsaker F. D. (2006). Social Behavior and Peer Relationships of Victims, Bully-Victim, and Bullies in Kindergarten. Journal of Child Psychology and Psychiatry, 45-57.

Petrie, K. (2014). The Relationships Between School Climate and Student Bullying. Teach Journal of Christian Education, 8 (1).

Qodar, N. (2015). Survei ICRW: 84\% Anak Indonesia Alami Kekerasan di Sekolah. Diunduh $\begin{array}{lllll}\text { pada tanggal } & 24 & \text { Januari } & 2016\end{array}$ http://news.liputan6.com/read/2191106/survei-icrw-84-anak-indonesia-alamikekerasan-di-sekolah

Rina. (2016). Waduh! Masih Ada Bullying di SMA 6 Jakarta. Diunduh pada tanggal 28 September 2016 dari http://www.pos-metro.com/2016/07/ waduh-masih-adabullying-di-sma-6.html 
Rudi, A. (2016). Siswa Pelaku "Bullying" di SMAN 3 Tidak Diluluskan. Diunduh pada tanggal 28 September 2016 dari http://megapolitan.kompas.com/ read/2016/05/09/10295511/Siswa.Pelaku.Bullying.di.SMAN.3.Tidak. Diluluskan

Sanson, A. \& Smart, D. (2003). Social Competence in Young Adulthood:Its Nature and Antecedents. Journal Family Matters No. 64 Autumn 2003.

Setyawan, D. (2016). KPAI : 'Quo Vadis' Perlindungan Anak di Sekolah: Antara Norma dan Realita. Di unduh tanggal 24 Januari 2016 dari http://www.kpai.go.id/berita/kpai-quo-vadis-perlindungan-anak-di-sekolahantara-norma-dan-realita/

Susanti, A. (2015). Daftar Kasus Bullying yang Dilakukan Siswa. Di unduh pada tanggal $26 \quad$ oktober $2016 \quad$ dari http://news.okezone.com/read/2015/12/15/65/1267586/daftar-kasus-bullyingyang-dilakukan-siswa

Swearer, S. M., Hymel, S. (2015). Understanding the Psychology of Bullying : Moving Toward a Social-Ecological Diathesis-Stress Model. 344-353.

Taki, M. (2001). Japanese School Bullying : Ijime. National Institute for Educational Policy Reasearch of Japan.

Tamtomo, A. (2014). Hubungan Antara Stres Sekolah dan Dukungan Teman Sebaya Terhadap Perilaku Bullying pada siswa. Tesis. Surakarta : Universitas Muhammadiyah Surakarta.

Ttofi, M.M., \& Farrington, D.P. (2011). Effectiveness of School-Based Programs to Reduce Bullying: A Systematic and Meta-Analytic Review. Journal Experiment Criminologi, 27-56

Yoneyama, S., \& Naito, A. (2010). Problems with the Paradigm: The school as a factor in understanding bullying (with special reference to Japan). British Journal of Sociology of Education, 315-330. 